\title{
研究論文
}

\section{人工心肺回路充填液へのアルブミン投与と体外循環中の 晶質液輸液制限の併用が水分バランスに与える臨床的効果}

\author{
畑中祐也 ${ }^{1)} \cdot$ 八木克史 ${ }^{1)} \cdot$ 菅原浩樹 ${ }^{1)} \cdot$ 吉田 諭 ${ }^{1)}$ \\ 山本知里 ${ }^{1)} \cdot$ 吉田匡毅 ${ }^{1)} \cdot$ 夜久 均 ${ }^{2)}$
}

\begin{abstract}
要旨
アルブミン製剤を充填液に投与し、かつ体外循環中の晶質液輸液を制限する効果について、後方視的に研究を行 った。対象は当院で 2008 年 11 月から 2012 年 7 月に行われた成人開心術 120 例とし、人工心肺回路への蛋白投与 の有無と体外循環中の晶質液輸液制限の有無により 4 群に分類し、比較検討した。体外循環中の $5 \%$ アルブミン製 剤の投与は制限しなかった。アルブミンを充填液へ投与せず、晶質液輸液制限をしなかった群では有意に水分バラ ンスが多量となった。体外循環中のアルブミン投与量は各群間で有意差がなく、人工心肺充填液へのアルブミン投 与は慎重に行われる必要があるが、晶質液輸夜を行っても適切にアルブミンを投与することにより、人工心肺中の 水分バランスは抑制されることが示唆された。
\end{abstract}

索引用語：アルブミン、晶質液輸液、水分バランス

The clinical effect on fluid balance of albumin in the priming solution and restriction on crystalloid loading during cardiopulmonary bypass

Yuya Hatanaka ${ }^{1)}$, Yoshifumi Yagi ${ }^{1)}$, Hiroki Sugawara ${ }^{1)}$, Satoshi Yoshida ${ }^{1)}$, Chisato Yamamoto ${ }^{1)}$, Masaki Yoshida ${ }^{1)}$, Hitoshi Yaku ${ }^{2)}$

Key words : albumin, crystalloid loading, fluid balance

\section{I．緒言}

輸液製椷としての膠質液と晶質液については、長年 にわたり比較検討され、議論されてきた。

集中治療領域における研究では、膠質液の使用によ る死亡率の統計学的に有意な低下は認められていない が 1-4)、SOFAscore が改善した報告 ${ }^{1)}$ や、水分バラン スおよび肺コンプライアンスについて良好な結果を得 た報告 ${ }^{2}$ がなされている。また、有意差はないものの、 死亡率についての改善傾向が認められた報告 ${ }^{4}$ もある。 水分バランスについては、その増加が入院期間延長 ${ }^{5}$ 、

1) 京都府立医科大学附属病院 医療機器管理部

畑中祐也 (Yuya Hatanaka)

₹ 602-8566 京都市上京区河原町通広小路上る梶井町 465

Department of Clinical Engineer, University Hospital, Kyoto Prefectural University of Medicine

465 Kajii-cho, Kawaramachi-hirokoji, Kamigyo-ku, Kyoto, 602-8566, Japan

2) 京都府立医科大学 外科学教室 心臟血管外科学部門

[原稿受領日：2013 年 2 月 5 日 採択日：2013 年 4 月 9 日]
急性肺傷害患者における挿管時間や集中治療室入院期 間の増加 ${ }^{6}$ および急性腎傷害における死亡リスクの独 立因子となった報告もあり ${ }^{7)}$ 、晶質液輸液が肺浮腫の 原因との研究結果もある ${ }^{8)}$ 。肺血管外水分量の増加は 肺胞気動脈血酸素分圧較差を開大させる因子であり ${ }^{9)}$ 、 過剰な水分バランスの増加は呼吸機能および腎機能へ 悪影響を及ぼす可能性がある。これらのことより、ア ルブミンが晶質液と比較して血管内容量を効率的に増 加させ水分バランスを抑制する作用については、一定 の臨床的効果があると考えることもできる。

また、低アルブミン血症が生命予後を悪化させる因 子との研究結果も報告されており 10)、アルブミン投与 が予後に与える影響に関しては、現在も議論されてい る。

人工心肺 (cardiopulmonary bypass : CPB) を使用 した開心術症例に関しては、充填液へのアルブミン投 与が及ぼす効果についての報告が散見され、体重増加 や挿管時間については有意差のなかった研究結果が報 告されているが 11-16)、水分バランスや肺血管外水分量 で有意に良好な結果を報告した研究もある ${ }^{12-15) 。 ~}$ 
表 1 術 式

\begin{tabular}{|c|c|c|c|c|}
\hline & $\mathrm{C}$ 群（例） & $\mathrm{R}$ 群 (例) & $\mathrm{A}$ 群 (例) & $\mathrm{AR}$ 群(例) \\
\hline 弁置換（弁形成） & 40 & 4 & 6 & 10 \\
\hline 弁置換（弁形成）+Maze（PVisolation） & 15 & 4 & 1 & 2 \\
\hline 弁置換 (弁形成) +CABG & 7 & 1 & 4 & 2 \\
\hline 弁置換（弁形成 $)+C A B G+$ Maze（PVisolation） & 2 & 1 & 0 & 1 \\
\hline CABG + Maze（PVisolation $)$ & 1 & 0 & 0 & 0 \\
\hline 弁置換 +上行大動脈人工血管置換術 & 1 & 0 & 0 & 0 \\
\hline バルサルバ洞動脈瘤修復術 & 0 & 1 & 0 & 0 \\
\hline Bentall & 3 & 0 & 0 & 0 \\
\hline Bentall + Maze & 0 & 0 & 1 & 0 \\
\hline CABG + 左心室形成術 & 2 & 0 & 1 & 1 \\
\hline 左房内粘液腫摘除術 & 4 & 3 & 0 & 0 \\
\hline 右房内粘液腫摘除術 & 1 & 1 & 0 & 0 \\
\hline
\end{tabular}

C 群 : crystalloid priming with no restriction on crystalloid loading

$\mathrm{R}$ 群 : crystalloid priming with restriction on crystalloid loading

A 群 : albumin in the priming solution with no restriction on crystalloid loading

AR 群 : albumin in the priming solution with restriction on crystalloid loading

当施設では、 $\mathrm{CPB}$ 回路充填液へのアルブミン投与に 加え、体外循環中の晶質液輸液を制限することが、よ り水分バランスを抑制するとの仮説を立て、2008 年の 11 月より、充填液への積極的なアルブミン投与と体外 循環中の晶質液輸液の制限を行った。

充填液へのアルブミン製剤投与に加え、体外循環中 の晶質液輸液を制限した研究はなく、当施設での仮説 を検証することを目的に、今回、充填液へのアルブミ ン投与と体外循環中の晶質液輸液制限の水分バランス に対する臨床的効果について、後方視的に比較検討し たので報告する。

\section{II. 対}

2008 年 11 月から 2012 年 7 月に行われた $\mathrm{CPB}$ を用 いた成人開心術症例のうち、脳分離体外循環症例、術 中透析施行例、再手術症例を除外し、体外循環中のデ ータが検索可能な 120 例を対象とした。

\section{III. 方 法}

体外循環開始後の予想へマトクリット值が $20 \%$ 以下 となり、CPB 回路充填液中に濃厚赤血球液 (RCC-LR)

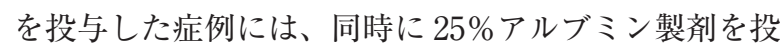
与し、体外循環中に補液が必要と判断された場合には、 $5 \%$ CPB 回路に RCC-LR を投与しなかった症例では、充 填液へのアルブミン製剤を投与せず、晶質液で充填し た。

CPB 回路へ RCC-LR を投与しなかった場合でも、体 外循環中のへマトクリット值低下により RCC-LR 投与 が必要と判断された症例では、補液用製郕として $5 \%$
アルブミン製剂を選択し、晶質液輸液は制限した。

対象症例のうち、 $\mathrm{CPB}$ 回路を晶質液で充填し、体外 循環中に晶質液輸液を制限しなかった 76 例を $\mathrm{C}$ 群、 $\mathrm{CPB}$ 回路を晶質液で充填し、体外循環中には晶質液輸液制 限を行い、補液が必要と判断された場合には $5 \%$ アル ブミン製剂を使用した 15 例を $\mathrm{R}$ 群、 $\mathrm{CPB}$ 回路の充填 液に $25 \%$ アルブミン製剤を投与するが、体外循環中に は晶質液輸液を制限しなかった 13 例を $\mathrm{A}$ 群、 $\mathrm{CPB}$ 回 路の充填液に $25 \%$ アルブミン製剤を投与し、更に体外 循環中は晶質液輸液制限を行い、補液には $5 \%$ アルブ ミン製剂を用いた 16 例を $\mathrm{AR}$ 群とした。各群における 対象症例の術式は、表 1 に示す内容となった。

晶質液輸液を制限しなかった群においても、晶質液 輸液単独では血液希釈が高度になると判断された場合 には、5\%アルブミン製剤を使用した。

人工肺は、最大血流量が $5 \mathrm{~L} / \mathrm{min}$ の人工肺 (Quadroxi small adult ${ }^{\circledR}:$ MAQUET、CX-FX-15 ${ }^{\circledR}$ また CX-RX-15 ${ }^{\circledR}$ : テルモ) と、最大血流量が $7 \mathrm{~L} / \mathrm{min}$ の人工肺 (Quadroxi ${ }^{\circledR}$ :

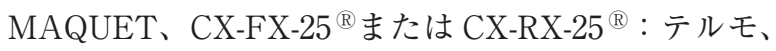
D903AVANT ${ }^{\circledR}$ : SORIN、HPO-23WH-C ${ }^{\circledR}$ : 泉工医科 工業) を適正灌流量に適合させて使用した。静脈リザ ーバには心内血貯血槽一体型（CX-RR40 ${ }^{\circledR}$ : テルモ）を 使用し、動脈フィルタ内蔵ではない人工肺を使用する症 例では、動脈フィルタ (Affinity ${ }^{\circledR}:$ Medtronic、AL-6 ${ }^{\circledR}$ : 日本ポール、QUART ${ }^{\circledR}$ ：MAQUET）を使用した。人 工心肺回路は $\mathrm{L}$ 回路と $\mathrm{M}$ 回路を人工肺のサイズに適 合させて使用した。L 回路の充填液量は $1,250 \mathrm{~mL}$ で、 $\mathrm{M}$ 回路の充填液量は $850 \mathrm{~mL}$ であった。

全例でローラーポンプ送血（HL-30 ${ }^{\circledR}:$ MAQUET) と吸引補助脱血を行った。 
表 2 基礎データの比較

\begin{tabular}{lccccc}
\hline & $\mathrm{C}$ 群 $(\mathrm{n}=76)$ & $\mathrm{R}$ 群 $(\mathrm{n}=15)$ & $\mathrm{A}$ 群 $(\mathrm{n}=13)$ & $\mathrm{AR}$ 群 $(\mathrm{n}=16)$ & $\mathrm{P}$ value \\
\hline 身 長 $(\mathrm{cm})$ & $162.5 \pm 9.9$ & $159.8 \pm 9.1$ & $163.7 \pm 9.0$ & $165.5 \pm 7.2$ & n.s. \\
体 重 $(\mathrm{kg})$ & $60.3 \pm 12.7$ & $56.7 \pm 9.3$ & $57.6 \pm 12.1$ & $61.0 \pm 10.1$ & n.s. \\
年 齢 $(\mathrm{y})$ & $62.3 \pm 12.0$ & $66.7 \pm 12.6$ & $69.2 \pm 8.0$ & $72.0 \pm 7.9$ & $<0.05^{*}$ \\
$\mathrm{CPB}$ time $(\mathrm{min})$ & $175.3 \pm 53.6$ & $155.5 \pm 45.3$ & $187.8 \pm 40.4$ & $189.5 \pm 34.4$ & n.s. \\
$\mathrm{ACC}$ time $(\mathrm{min})$ & $117.5 \pm 43.1$ & $100.8 \pm 29.8$ & $122.3 \pm 33.6$ & $129.7 \pm 28.7$ & n.s. \\
手術前血清アルブミン值 $(\mathrm{g} / \mathrm{dL})$ & $4.5 \pm 0.8$ & $4.2 \pm 0.3$ & $3.9 \pm 0.6$ & $3.9 \pm 0.6$ & n.s. \\
\hline
\end{tabular}

CPB time : cardio pulmonary bypass time ; ACC time : aortic cross clamp time n.s. : not significant * : C 群 vs A 群

人工心肺回路充填液には、無輸血体外循環を目標と する症例で晶質液を選択した。 RCC-LR を投与する場 合には、25\%アルブミン製剤を体外循環開始直後の予 想アルブミン值を参考に $150 \mathrm{~mL}$ から $250 \mathrm{~mL}$ 使用した。

晶質液による人工心肺回路充填液には、重炭酸ナト リウム（メイロン®静注 7\%） $3 \mathrm{~mL} / \mathrm{kg}$ 、マンニトール （20\%マンニットール®注射液） $5 \mathrm{~mL} / \mathrm{kg}$ 、副腎皮質ステ ロイド剤（ソル・メドロール®） $1,000 \mathrm{mg}$ 、抗生物質製 剂、乳酸リンゲル液 (ソルラクト ${ }^{\circledR}$ ) を使用した。人 工心肺回路の充填に RCC-LR を使用する場合には、滤 過型人工腎臟用補液 (サブラッド ${ }^{\circledR}$ 血液滤過用補充液 BS または BSG）で洗浄した。

麻酔科医による体外循環前後のアルブミンまたは晶 質液の投与については、制限しなかった。

採取項目は、人工心肺回路充填液へのアルブミン投 与量、体外循環中の補液量、水分バランス、体外循環 中の投与アルブミン量、充填液への投与も含めた総投 与アルブミン量、体重増加量とした。比較検討するに あたり、水分バランスとアルブミン量は体重で除し、 手術後の体重増加量は手術前からの体重増加率に換算 した。

統計学的検討には statmate IV ウィンドウズ版を使 用した。統計学的解析方法には Kruskal-wallis 検定を 使用して $\mathrm{p}<0.05$ で有意とし、各群間の多重比較には Dunn 法を使用して $\mathrm{p}<0.05$ で有意とした。比較デー 夕は中央値と四分位範囲で示した。

本稿におけるすべての著者について開示すべき COI はなく、本研究は京都府立医科大学倫理審查委員会に 承認された（E-448）。

\section{IV. 結 果}

各群間における基礎データの比較では C 群と A 群 間で年齢に有意差を認められたが、その他の項目では 有意差を認められなかった。手術前の血清アルブミン 值についても、各群間で有意差を認められなかった(表 2)。

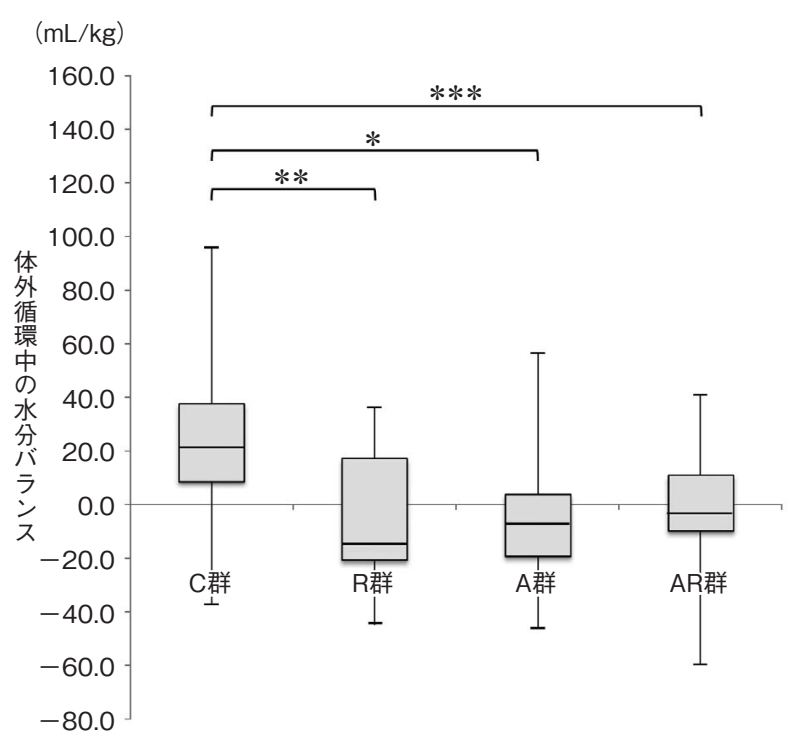

図 1 体外循環中の水分バランス

体外循環中の水分バランス $(\mathrm{mL} / \mathrm{kg})=$ 体外循環中の水分バランス $(\mathrm{mL})$ / 体重 $(\mathrm{kg})$

中央值 ; C 群 : $21.0 \mathrm{~mL} / \mathrm{kg} 、 \mathrm{R}$ 群 : $-15.0 \mathrm{~mL} / \mathrm{kg} 、 \mathrm{~A}$ 群 : $-7.9 \mathrm{~mL} / \mathrm{kg}$ 、 AR 群 : $-3.4 \mathrm{~mL} / \mathrm{kg}$

* : p < 0.05、C 群 vs A 群

**: $\mathrm{p}<0.01$ 、C 群 vs R 群

*** : $\mathrm{p}<0.001 、 \mathrm{C}$ 群 vs AR 群

人工心肺回路の充填に使用したアルブミン量は、A 群が 1.0 [0.6、1.1] g/kg、AR 群が 1.0 [0.9、1.1] g/ $/ \mathrm{kg}$ で有意差は認められず、体外循環中の補液量は、C 群 が 25.9 [9.2、47.9］ mL/kg で、A 群は 32.8 [6.2、65.5] $\mathrm{mL} / \mathrm{kg}$ となり、有意差は認められなかった。

水分バランスは、C 群 21.0 [8.8、37.5] mL/kg、 R 群 -15.0 [-20.7、17.2] mL/kg、A 群 -7.9 [-19.2、 $3.6] \mathrm{mL} / \mathrm{kg} 、 \mathrm{AR}$ 群 -3.4 [-10.0、11.2] $\mathrm{mL} / \mathrm{kg}$ とな り、C 群と $\mathrm{R}$ 群 $(\mathrm{p}<0.01) 、 \mathrm{C}$ 群と A 群 $(\mathrm{p}<0.05)$ 、 $\mathrm{C}$ 群と $\mathrm{AR}$ 群 $(\mathrm{p}<0.001)$ で有意差が認められた (図 1)。 体外循環中に投与されたアルブミン量に各群間での 有意差はなく、C 群 $0.0[0.0 、 0.7] \mathrm{g} / \mathrm{kg} 、 \mathrm{R}$ 群 $0.8[0.0$ 、 $1.1] \mathrm{g} / \mathrm{kg} 、 \mathrm{~A}$ 群 $0.3[0.2 、 0.7] \mathrm{g} / \mathrm{kg} 、 \mathrm{AR}$ 群 0.5 [0.0、 $0.9] \mathrm{g} / \mathrm{kg}$ となった（図2）。 


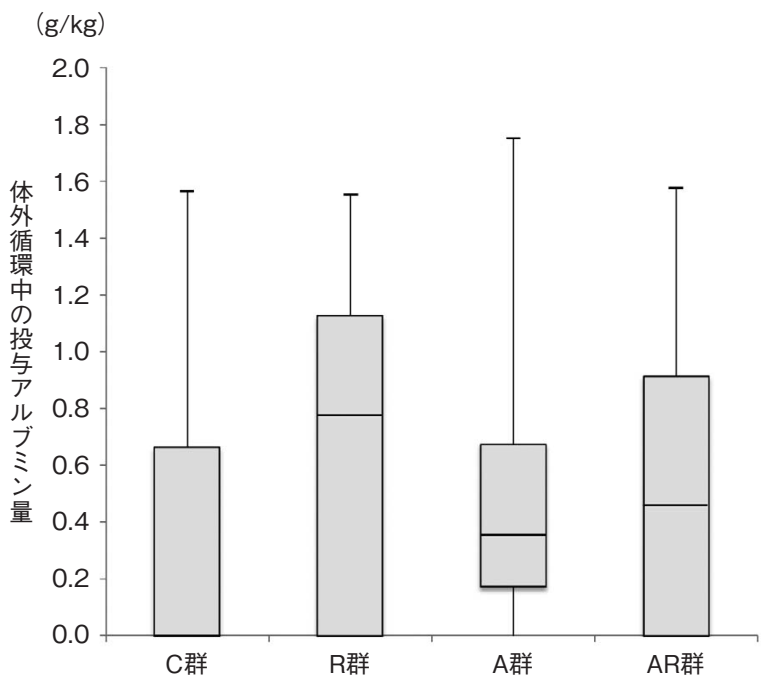

図 2 体外循環中のアルブミン投与量

体外循環中のアルブミン投与量 $(\mathrm{g} / \mathrm{kg})=$ 体外循環中のアルブミン投与 量 $(\mathrm{g})$ / 体重 $(\mathrm{kg})$

中央值; C 群 : $0.0 \mathrm{~g} / \mathrm{kg} 、 \mathrm{R}$ 群 $: 0.8 \mathrm{~g} / \mathrm{kg} 、 \mathrm{~A}$ 群 $: 0.3 \mathrm{~g} / \mathrm{kg} 、 \mathrm{AR}$ 群 $: 0.5 \mathrm{~g} /$ $\mathrm{kg}$

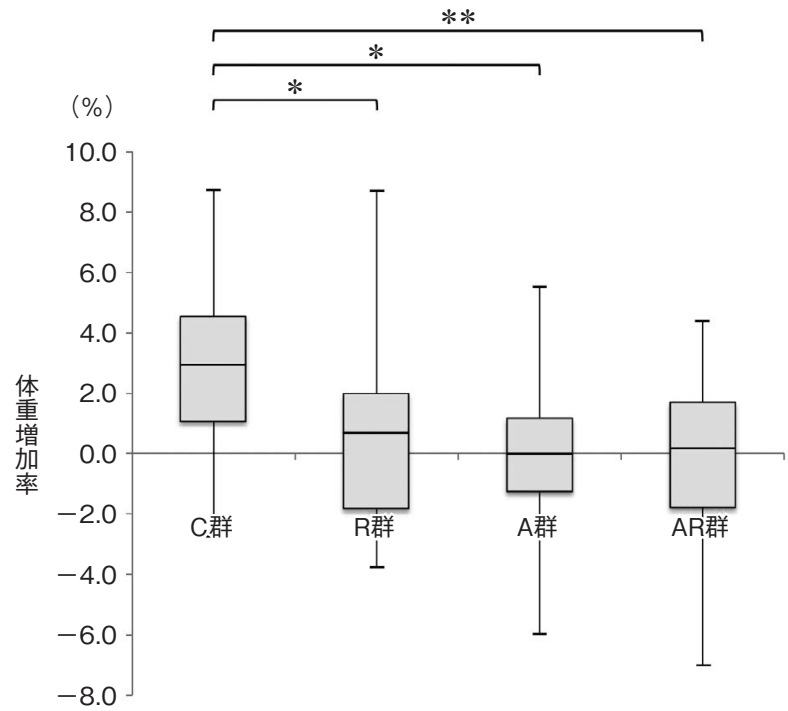

図 4 体重増加率

体重増加率 $=$ 体重増加量 $/$ 手術前体重 $\times 100$

中央値；C 群 : $2.9 \%$ 、 R 群 : $0.6 \% 、 \mathrm{~A}$ 群 : $0.0 \% 、 \mathrm{AR}$ 群 : $0.2 \%$

$*: \mathrm{p}<0.05 、 \mathrm{C}$ 群 vs R 群、C 群 vs A 群

** : $\mathrm{p}<0.01$ 、C 群 vs AR 群

人工心肺回路充填液中への投与も含めた総投与アル ブミン量は、C 群 0.0 [0.0、0.7］ g/kg、R 群 0.8 [0.0、 $1.1] \mathrm{g} / \mathrm{kg} 、 \mathrm{~A}$ 群 1.4 [0.8、1.1] g/kg、AR群 1.5 [0.9、 $1.8] \mathrm{g} / \mathrm{kg}$ 群となり、C 群とA 群 $(\mathrm{p}<0.001) 、 \mathrm{C}$ 群と $\mathrm{AR}$ 群（p<0.001）で有意差を認められた（図 3）。

体重増加率は、C 群 2.9 [1.1、4.5］％、R 群 0.6 [$1.8 、 2.0] \% 、 \mathrm{~A}$ 群 0.0 [-1.3、1.2] \%、AR 群 $0.2[-$ $1.8 、 1.7] \%$ となり、C 群と R 群（ $\mathrm{p}<0.05 ） 、 \mathrm{C}$ 群と A

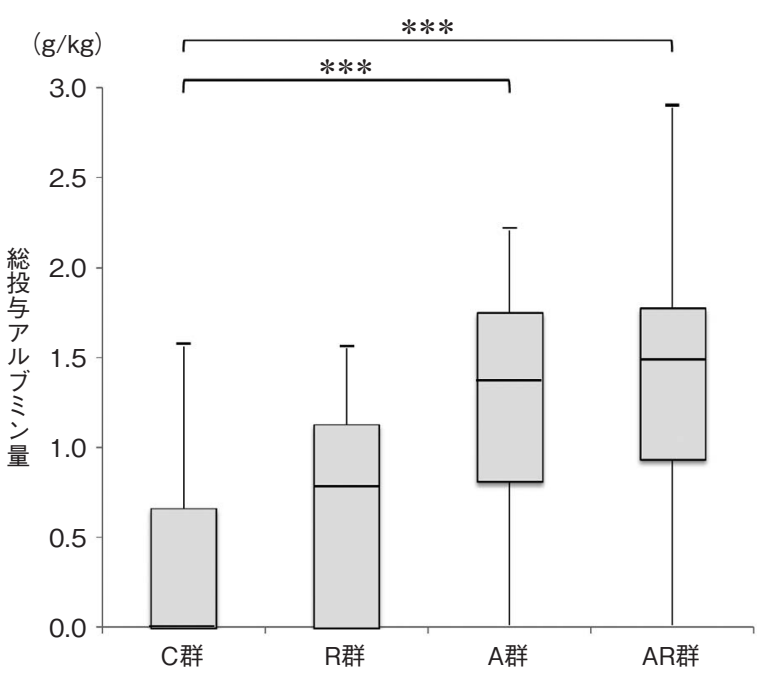

図 3 総アルブミン投与量

総アルブミン投与量 $(\mathrm{g} / \mathrm{kg})$ ) 総アルブミン投与量 $(\mathrm{g})$ / 体重 $(\mathrm{kg})$ 中央值 ; C 群 : $0.0 \mathrm{~g} / \mathrm{kg} 、 \mathrm{R}$ 群 : $0.8 \mathrm{~g} / \mathrm{kg} 、 \mathrm{~A}$ 群 $: 1.4 \mathrm{~g} / \mathrm{kg} 、 \mathrm{AR}$ 群 $: 1.5 \mathrm{~g} /$ $\mathrm{kg}$ **** : p < 0.001、C 群 vs A 群、C 群 vs AR 群

群（p<0.05）、C 群と AR 群（ $\mathrm{p}<0.01 ） て ゙$ 有意差を認 められた（図 4）。

\section{V. 考察}

今回の研究ではすべての群で体外循環中のアルブミ ン投与に制限を設けなかったが、C 群については、他 の群に比較して水分バランスが増加する結果となった。

人工心肺回路充填液へのアルブミン投与に関して、 比較的少量のアルブミンを投与した場合には良好な結 果を得られない可能性があるとする研究が存在し ${ }^{16)}$ 、 また、充填液中のアルブミン濃度を $2.6 \%$ から $5.0 \%$ と 比較的高濃度とした研究では ${ }^{12-15)}$ 、体外循環中の水分 バランスに関して良好な結果を得た報告があることか ら、当院における充填液へのアルブミン投与時には、 $25 \%$ アルブミン製剤を 3 本から 5 本と比較的高濃度に している。

$\mathrm{A}$ 群および $\mathrm{AR}$ 群に関する水分バランスの結果につ いては、C 群と同様に体外循環中の晶質液輸液を制限 しなかった $\mathrm{A}$ 群に打いても $\mathrm{C}$ 群と比較して有意に水 分バランスが抑制された結果より、充填液へのアルブ ミン投与が水分バランス抑制に対して一定の効果があ ると考えることができるが、充填液へのアルブミン投 与をしなかった $\mathrm{R}$ 群についても $\mathrm{C}$ 群に比較して有意に 水分バランスがマイナスとなった結果については、他 の原因を検索する必要がある。

今回の研究で体外循環中のアルブミン投与を制限し なかった結果、体外循環中のアルブミン投与量は各群 間で有意差がなかった。また、体外循環前後の麻酔科 
医によるアルブミン投与に関しても、制限を設けなか った。その結果、体外循環開始時には、ある程度の血 清アルブミン值が維持され、また体外循環中の血清ア ルブミン值も維持された症例が存在する可能性があり、 そのことが $\mathrm{R}$ 群の水分バランス結果の原因となった可 能性は否定できない。

また、 $\mathrm{R}$ 群は $\mathrm{A}$ 群抢よび $\mathrm{AR}$ 群と比較し、水分バラ ンス結果に偏差が生じた。

血管内に投与された晶質液は血管外の細胞間質等へ 漏出し、膠質液と同等の血漿増量効果を得るためには、 膠質液の 3 倍から 4 倍量が必要であることから推察す ると ${ }^{17)}$ 、人工心肺回路充填液が晶質液である場合、体 外循環開始時に血管内へ流入した充填液の多くが血管 外へ漏出すると考えることができる。

それらを可能な限り抑制するためには、人工心肺回 路充填液中へアルブミンを投与し、充填液のアルブミ ン濃度を一定以上に維持する必要があると考えられる が、充填液へのアルブミン投与をしなかった $\mathrm{R}$ 群の一 部では、体外循環開始前に麻酔科医からアルブミンが 投与されなかった場合、体外循環開始と同時に血漿膠 質浸透圧の急激な低下が起こり、充填液の血管外への 漏出が起こった可能性があり、 $\mathrm{R}$ 群の偏差の原因と考 えることができる。

しかし、アルブミン製剤の薬価は乳酸リンゲル液の 20 倍以上と高価であり、費用対効果の観点から考慮す ると、アルブミン製剤の使用は必要最小限に抑制され る必要がある。今回の研究で行われた充填液への投与 も含めた総投与アルブミン量では、 $\mathrm{R}$ 群と $\mathrm{A}$ 群抒よび $\mathrm{AR}$ 群の間で有意差があり、その原因は充填液へのア ルブミン投与量にあると考えられるが、水分バランス では有意差が認められなかった。この結果より、総ア ルブミン量を抑制し水分バランスについて良好な結果 を得るには、充填液へのアルブミン投与量は慎重に決 定される必要があると考えることができる。

人工心肺回路充填液へアルブミンを投与するが、体 外循環中の晶質液輸液制限を行わなかった $\mathrm{A}$ 群につい ては、晶質液輸液量の中央值が $32.8 \mathrm{~mL} / \mathrm{kg}$ と 4 群間で 最も多量であるが、水分バランスについては C 群と比 較して有意に低值を認められた。人工心肺回路充填液 へのアルブミン投与が $\mathrm{C}$ 群との間で有意差を認められ た原因と考えることができるが、充填液へのアルブミ ン投与量に体外循環中の投与量を加えた総アルブミン 投与量は中央值で $1.4 \mathrm{~g} / \mathrm{kg}$ となり、C 群の $0.0 \mathrm{~g} / \mathrm{kg} （ 75$ パーセンタイル值 $; 0.7 \mathrm{~g} / \mathrm{kg})$ との間で有意差はないも のの多量になる傾向を認められたことから、血漿膠質 浸透圧が適切に維持されていれば、体外循環中の補液 に晶質液を使用しても水分バランスを抑制できる可能 性がある。
アルブミン投与についての集中治療領域における比 較的大規模な研究では、28 日死亡率や人工呼吸期間で は生理食塩水投与群との間で有意差がなく、その有効 性は認められなかった3)。しかしその後、同デー夕を 投与前のアルブミン值で 2 群に分類した研究では、血 清アルブミン值が $25 \mathrm{~g} / \mathrm{L}$ 未満の群において、有意差は ないものの死亡率で改善傾向が認められた ${ }^{4)}$ 。今回の 研究で手術前のアルブミン值においては各群間で有意 差がなく、体外循環中の血清アルブミン值については 検查していない。膠質浸透圧の維持による血管外水分 量の抑制を目的としたアルブミン投与では、手術前抒 よび体外循環中の血清アルブミン值を考虑する必要が ある。

また、アルブミン投与により呼吸機能を維持し、手 術後の人工呼吸期間や集中治療室入院期間を減少させ ることを目的とするには、体外循環中のみならず周術 期で総合的に膠質浸透圧を維持する必要があると考え られ、今後は体外循環前後も含めた周術期でのアルブ ミン投与の有效性を検討したい。

\section{VI. 結 果}

人工心肺充填液へのアルブミン投与は慎重に行う必 要があるが、晶質液輸液を行っても適切にアルブミン を投与することにより、人工心肺中の水分バランスは 抑制されることが示唆された。

\section{参考文献}

1) Dubois MJ, Orellana-Jimenez C, Vincent JL, et al. : Albumin administration improves organ function in critically ill hypoalbuminemic patients: A prospective, randomized, controlled, pilot study. Crit Care Med, 34 (10) ; 2536-2540, 2006.

2) Verheij J, van Lingen A, Groeneveld AB, et al. : Effect of fluid loading with saline or colloids on pulmonary permeability, oedema and lung injury score affter cardiac and major vascular surgery. Br J Anaesth, 96 (1) ; 21-30, 2006.

3) Finfer S, Bellomo R, Norton R, et al. : The SAFE Study Investigators: A Comparison of albumin and saline for fluid resuscitation in the intensive care unit. N Engl J Med, 350 (22) ; 2247-2256, 2004.

4) Finfer $\mathrm{S}$, Bellomo R, Norton R, et al. : SAFE Study Investigators : Effect of baseline serum albumin concentration on outcome of resuscitation with albumin or saline in patients in intensive care units : analysis data from the saline versus albumin fluid evaluation. BMJ, 333 (7577) ; 1044-1049, 2006.

5) Toraman F, Evrenkaya S, Alhan C, et al. : Highly positive intraoperative fluid balance during cardiac surgery is associated with adverse outcome. Perfusion, 19 (2) ; 85-91, 2004.

6) Wiedemann HP, Wheeler AP, Harabin AL, et al. : National Heart, Lung, and Blood Institute Acute Respiratory Distress 
Syndrome (ARDS) Clinical Trials Network : Comparison of two fluid-management strategies in acute lung injury. New Engl J Med, 354 (24) ; 2564-2575, 2006.

7) Payen D, de Pont AC, Vincent JL, et al. : Sepsis Occurrence in Acutely Ill Patients (SOAP) Investigators : A positive fluid balanve is associated with a worse outcome in patients with acute renal failure. Crit Care, 12 (3) ; R74, 2008.

8) Stein L, Beraud JJ, Shubin H, et al. : pulmonary edema during volume infusion. Circulation, 52 (3) ; 483-489, 1975.

9) Lumb PD : A comparison between $25 \%$ albumin and $6 \%$ hydroxyethyl starch solutions on lung water accumulation during and immediately after cardiopulmonary bypass. Ann Surg, 206 (2) ; 210-213, 1987.

10) Vincent JL, Dubois MJ, Wilkes MM, et al: Hypoalbuminemia in acute illness : Is there a rationale for intervention? A meta-analysis of cohort studies and controlled trials. Ann Surg, 237 (3) ; 319-334, 2003.

11) Russell JA, Navickis RJ, Wilkes MM : Albumin versus crystalloid for pump priming in cardiac surgery : metaanalysis of controlled trials. J Cardiothorac Vasc Anesth, 18 (4) ; 429-437, 2004.

12) Hoeft A, Korb H, Sonntag H, et al. : Priming of cardiopulmonary bypass with human albumin or ringer lactate : Effect on colloid osmotic pressure and extravascular lung water. Br J Anaesth, 66 (1) ; 73-80, 1991
13) Jenkins IR, Curtis AP : The combination of mannitol and albumin in the priming solution reduces positive intraoperative fluid balance during cardiopulmonary bypass. Perfusion, 10 (5) ; 301-305, 1995.

14) Scott DA, Hore PJ, Mullaly J, et al. : A comparison of albumin, polygeline and crystalloid priming solutions for cardiopulmonary bypass in patients having coronary artery bypass graft surgery. Perfusion, 10 (6) ; 415-424, 1995.

15) Aukerman J, Voepel-Lewis T, Mosca R, et al. : The relationship between extracorpoteal circuit prime, albumin, and postoperative weight gain in children. J Cardiothorac Vasc Anesth, 12 (4) ; 408-414, 1998.

16) Zarro DL, Palanzo DA, Phillips TG: Albumin in the pump prime : its effect on postoperative weight gain. Perfusion, 16 (2) ; 129-135, 2001.

17） Paul L.Marino（稲田英一監訳）：ICU ブック．第 3 版, 東京, メディカル・サイエンス・インターナショナル，2008. p202219. 